\title{
Pembelajaran Berbasis Masalah dan Inkuiri dalam Kemampuan Representasi Matematis
}

\author{
Iyam Maryati $^{1 *}$, Vera Monica ${ }^{2}$ \\ Program Studi Pendidikan Matematika, Institut Pendidikan Indonesia Garut \\ Jalan Pahlawan No 32 Sukagalih Tarogong Kidul Garut Indonesia \\ 1*iyammaryati@institutpendidikan.ac.id; ${ }^{2}$ veramonica@gmail.com
}

Artikel diterima: 13-11-2020, direvisi: 11-05-2021, diterbitkan: 31-05-2021

\begin{abstract}
Abstrak
Urgensi kemampuan representasi matematis dalam kehidupan nyata mendorong dilakukannya penelitian ini. Penerapan kegiatan proses pembelajaran yang tepat sangat diperlukan dalam peningkatan kemampuan representasi matematis ini. Tujuan dari penelitian ini adalah menganalisis perbandingan kemampuan representasi dan peningkatan matematis siswa antara yang mendapatkan model pembelajaran Pembelajaran berbasis Masalah dan model pembelajaran Inkuiri, menganalisis sikap siswa terhadap pembelajaran matematika yang mendapatkan model pembelajaran berbasis masalah dan model pembelajaran Inkuiri. Metode penelitian yang digunakan adalah kuasi eksperimen pada pokok bahasan Sistem Pertidaksamaan Dua Variabel. Populasi dalam penelitian ini adalah seluruh siswa kelas $X$ pada salah satu SMA di Kabupaten Garut sebanyak 66 orang. Instrumen yang digunakan adalah tes kemampuan representasi matematis siswa, lembar observasi dan angket. Hasil penelitian menyimpulkan bahwa kemampuan representasi matematis siswa yang mendapatkan model pembelajaran berbasis masalah lebih baik dibandingkan dengan siswa yang mendapatkan model pembelajaran Inkuiri. Dapat dikatakan bahwa Pembelajaran Berbasis Masalah memiliki pengaruh positif terhadap kemampuan representasi matematis siswa.

Kata Kunci: Inkuiri, Pembelajaran Berbasis Masalah, Representasi matematis.
\end{abstract}

\section{Problem-Based Learning and Inquiry in Mathematics Representation} Abilities

\begin{abstract}
The urgency of the ability of mathematical representation in real life drives the life of this research. The application of appropriate learning activities is very necessary for increasing the ability of this mathematical representation. The purpose of this study was to analyze the mathematical representation and improvement abilities of students who received the Problem-based learning model and the Inquiry learning model, to analyze students' attitudes towards mathematics learning who received the problem-based learning model and the Inquiry learning model. The research method used is quasi-experimental on the subject of Two-Variable Inequality Systems. The population in this study were all class $X$ students at one of the high schools in Garut Regency for the 2019/2020 academic year with a total sample of 66 students. The instruments used were tests of students mathematical representation abilities, observation sheets, and questionnaires. The results of the study concluded that the mathematical representation abilities of students who received the problem-based learning model were better than those who received the Inquiry learning model. It can be said that Problem Based Learning has a positive influence on students' mathematical representation abilities.

Keywords: Inquiry, Problem based learning, Mathematical Representation.
\end{abstract}




\section{Pendahuluan}

Tujuan pembelajaran matematika Kurikulum 2013 tercantum dalam Permendiknas No. 59 Tahun 2014 yaitu sebagai berikut.

a. Memahami konsep matematika, yaitu kompetensi untuk memberikan penjelasan kaitan antar konsep dan penerapan konsep maupun algoritma secara efektif dalam pemecahan masalah.

b. Menerapkan penalaran pada sifat, memanipulasi matematika baik dalam penyederhanaan, maupun penganalisaan komponen pemecahan masalah baik di dalam maupun di luar konteks matematika

c. Memiliki sikap menghargai kegunaan matematika dalam kehidupan, yaitu memiliki rasa ingin tahu, perhatian, dan minat dalam mempelajari matematika, serta sikap ulet dan percaya diri dalam pemecahan masalah.

Selain tujuan tersebut, terdapat pula standar pembelajaran matematika berdasarkan National Council of Teachers of Mathematics (2000) yaitu kemampuan pemecahan masalah (problem solving), kemampuan komunikasi (communication), kemampuan koneksi (connection), kemampuan penalaran (reasoning), dan kemampuan representasi (representation). Berdasarkan standar pembelajaran matematika tersebut, salah satu kemampuan matematis yang harus dimiliki dan dikembangkan oleh siswa adalah kemampuan representasi.

NCTM (Eviyanti, 2018) students in themiddle grades solve many problems in which they create and use representations to organize and record their thinking about mathematical ideas. Siswa mampu menerapkan strategi dalam pemecahan masalah yang baik apabila memiliki kemampuan representasi yang baik pula.

Siswa harus memiliki kemampuan representasi yang terus berkembang seiring dengan perubahan teknologi informasi (Damayanti \& Afriansyah, 2018). Namun, pada kenyataannya kemampuan representasi matematis siswa belum sepenuhnya baik. Hal ini dapat dilihat dari hasil penelitian yang dilakukan (Abdi \& Ikhsan, 2013; Amalia, Rusdi, \& Kamid, 2021) menunjukan hasil rata-rata tes soal matematika siswa SMA setara Programme for International Student Assessment (PISA) masih di bawah level satu, yang berarti siswa belum mampu menyelesaikan soal matematika setara PISA, padahal soal-soal PISA merupakan soal-soal literasi matematis yang dalam penyelesaiannya menuntut siswa untuk memiliki kemampuan representasi matematis.

Selain itu menurut penelitian yang dilakukan oleh (Handayani, 2014; Lestari, Andinasari, \& Retta, 2020) menunjukkan bahwa kemampuan representasi matematis siswa SMA masih dikategorikan rendah. Begitu juga data yang dihasilkan dari penelitian Putri (2017) diketahui bahwa persentase penggunaan aspek representasi matematis siswa SMA dalam menyelesaikan soal tes sebesar $36,1 \%$, hal ini menunjukkan bahwa masih kurangnya kemampuan representasi siswa SMA.

Menurut (Eviyanti, 2018) dalam penelitiannya menyatakan keammpuan representasi belum optimal disebabkan oleh keterbatasan pengetahuan guru dan kebiasaan siswa dalam pembelajaran secara konvensional. Akibat yang 
ditimbulkan dari keterbatasan kemampuan representasi adalah ketika siswa memecahkan masalah, cara penyelesaian yang digunakannya cenderung melihat unsur-unsur penting yang terkait dalam masalah tersebut, yang sebagian besar representasi simbolik, tanpa memperhatikan representasi dalam penampilan yang lain.

Maka diperlukan suatu usaha agar kemampuan representasi dapat meningkat. Salah satunya dengan penggunaan model pembelajaran yang sesuai. untuk meningkatkan kemampuan representasi secara optimal dalam pembelajaran matematika dapat dilakukan dengan menerapkan model pembelajaran yang menuntut siswa untuk mengeksplorasi, mengolah, menggunakan potensi, dan pengetahuan yang ada pada dirinya dalam menyelesaikan suatu permasalahan dengan semaksimal mungkin. Terdapat dua model pembelajaran yang digunakan dalam meningkatkan kemampuan representasi matematis yaitu model pembelajaran Pembelajaran berbasis Masalah dan model pembelajaran Inkuiri.

Dari penelitian yang dilakukan sebelumnya oleh (Fitri, Munzir, \& Duskri, 2017) menyatakan bahwa peningkatan kemampuan representasi matematis siswa yang memperoleh pembelajaran dengan model pembelajaran Pembelajaran berbasis Masalah lebih baik dari peningkatan kemampuan representasi matematis siswa yang memperoleh pembelajaran secara konvensional. Dari penelitian yang telah dilakukan Indikator visual pada kelas Pembelajaran berbasis Masalah mengalami peningkatan sebesar
$20 \%$, sedangkan untuk kelas konvensional meningkat sebesar $18,7 \%$. Sementara itu indikator verbal pada kelas Pembelajaran berbasis Masalah mengalami peningkatan sebesar 33,4\%, sedangkan untuk kelas konvensional meningkat sebesar 22,1\%. Dan untuk indikator simbolik kelas Pembelajaran berbasis Masalah meningkat $27,70 \%$, sedangkan kelas konvensional mengalami peningkatan sebesar $5 \%$.

Model pembelajaran Inkuiri merupakan kegiatan pembelajaran yang menekankan pada proses berpikir kritis dan analitis untuk mencari dan menemukan sendiri jawaban dari permasalahan yang ada. Menurut penelitian yang dilakukan oleh itu (Zaini, 2017) dalam penelitiannya menyatakan bahwa model pembelajaran Inkuiri efektif terhadap kemampuan representasi matematis siswa MAN kelas $\mathrm{XI}$, hal ini terlihat dari nilai rata-rata kelas yang diberi perlakuan model Inkuiri memperoleh nilai rata-rata 80,69 dengan nilai terkecil 69. Sedangkan kelas yang diberi model pembelajaran konvensional memperoleh nilai rata-rata 70,85 dengan nilai terkecil 0.

Melalui model pembelajaran Pembelajaran berbasis Masalah dan Inkuiri dapat memberikan kesempatan kepada siswa untuk membangun sendiri pengetahuan siswa. Oleh karena itu siswa mampu memecahkan masalah, dan termotivasi untuk belajar. Selain itu juga dapat melatih siswa untuk berpikir dan mengembangkan ide-ide matematis yang mereka miliki dalam bentuk kerja sama dalam kelompok-kelompok kecil.

Sikap yang positif terhadap matematika juga merupakan pengimbang untuk 
mencapai kompetensi dan hasil belajar matematika yang baik. Berdasarkan pengamatan penelitian (Lambertus, Ambarsari, \& Maonde, 2016) menyatakan bahwa salah satu faktor yang mempengaruhi rendahnya hasil belajar matematika siswa di sekolah adalah sikap siswa terhadap matematika. Matematika dianggap sebagai ilmu yang sangat sukar, tidak menarik dan bahkan membosankan. Menurut Ansjar (Lambertus, Ambarsari, \& Maonde, 2016) "untuk mengerti matematika, paling tidak orang tersebut harus menyenangi matematika". Sikap bukan hanya merupakan faktor yang sangat berperan dalam pembentukan karakter seseorang tetapi sikap juga merupakan motivasi yang sangat penting terhadap tingkah laku dan mempengaruhi seluruh pribadi seseorang,

Berdasarkan uraian tersebut Tujuan dari penelitian ini adalah menganalisis perbandingan kemampuan representasi dan peningkatan matematis siswa antara yang mendapatkan model pembelajaran Pembelajaran berbasis Masalah dan model pembelajaran Inkuiri, menganalisis sikap siswa terhadap pembelajaran matematika yang mendapatkan model pembelajaran Pembelajaran berbasis Masalah dan model pembelajaran Inkuiri.

Berdasarkan penelitian yang dilakukan sebelumnya oleh (Farhan, \& Retnawati, 2014; Guntara \& Nona, 2019) bahwa model pembelajaran Pembelajaran berbasis Masalah dan model pembelajaran Inkuiri efektif mampu meningkatkan kemampuan representasi matematis. Dalam penelitian ini, penulis ingin mengetahui sejauh mana peningkatan kemampuan representasi matematis siswa antara PBM dan inkuiri.
Model pembelajaran Pembelajaran berbasis Masalah efektif untuk meningkatkan kemampuan representasi matematis. (Maryati, 2016; Noer \& Gunowibowo, 2018; Annajmi \& Afri, 2019; Yenni \& Sukmawati, 2020).

Sintaks model Pembelajaran berbasis Masalah menurut Arends (Farhan \& Retnawati, 2014; Kusuma \& Candramila, 2017) disajikan pada Tabel 1 berikut.

Tabel 1.

Sintak Model Pembelajaran berbasis Masalah

\begin{tabular}{|c|c|}
\hline Fase & Perilaku Guru \\
\hline $\begin{array}{l}\text { Memberikan } \\
\text { orientasi tentang } \\
\text { permasalahannya } \\
\text { kepada siswa }\end{array}$ & $\begin{array}{l}\text { Guru membahas tujuan } \\
\text { pelajaran, mendeskripsikan } \\
\text { berbagai persiapan } \\
\text { kebutuhan logistik penting, } \\
\text { dan memotivasi siswa } \\
\text { untuk terlibat dalam } \\
\text { kegiatan mengatasi- } \\
\text { masalah. }\end{array}$ \\
\hline $\begin{array}{l}\text { Mengorganisasikan } \\
\text { siswa untuk belajar. }\end{array}$ & $\begin{array}{l}\text { Guru membantu siswa } \\
\text { untuk mendefinisikan dan } \\
\text { mengorganisasikan tugas- } \\
\text { tugas belajar yang terkait } \\
\text { dengan permasalahannya. }\end{array}$ \\
\hline $\begin{array}{l}\text { Membantu } \\
\text { investigasi mandiri } \\
\text { dan kelompok. }\end{array}$ & $\begin{array}{l}\text { Guru mendorong siswa } \\
\text { untuk mendapatkan } \\
\text { informasi yang tepat, } \\
\text { melaksanakan eksperimen, } \\
\text { dan mencari penjelasan } \\
\text { dan solusi }\end{array}$ \\
\hline $\begin{array}{l}\text { Mengembangkan } \\
\text { danmempresenta- } \\
\text { sikan artefak dan } \\
\text { exhibit. }\end{array}$ & $\begin{array}{l}\text { Guru membantu siswa } \\
\text { dalam merencanakan dan } \\
\text { menyiapkan artefak- } \\
\text { artefak yang tepat, seperti } \\
\text { laporan, rekaman video, } \\
\text { dan model-model, dan } \\
\text { membantu mereka untuk } \\
\text { menyampaikannya pada } \\
\text { orang lain. }\end{array}$ \\
\hline $\begin{array}{l}\text { Menganalisis dan } \\
\text { mengevaluasi } \\
\text { proses mengatasi } \\
\text { masalah. }\end{array}$ & $\begin{array}{l}\text { Guru membantu siswa } \\
\text { untuk melakukan refleksi } \\
\text { terhadap investigasinya } \\
\text { dan proses-proses yang } \\
\text { mereka gunakan }\end{array}$ \\
\hline
\end{tabular}

Sintaks model Inkuiri (Sanjaya, 2008) disajikan pada Tabel 2 berikut. 
Tabel 2.

Sintak Model Pembelajaran Inkuiri

\begin{tabular}{|c|c|}
\hline Fase & Perilaku Guru \\
\hline Orientasi & $\begin{array}{l}\text { Langkah orientasi adalah } \\
\text { langkah untuk membina } \\
\text { suasana atau iklim } \\
\text { pembelajaran } \\
\text { yang responsif. Pada langkah ini } \\
\text { guru mengkondisikan agar siswa } \\
\text { siap melaksanakan } \\
\text { proses pembelajaran }\end{array}$ \\
\hline $\begin{array}{l}\text { Merumuskan } \\
\text { Masalah }\end{array}$ & $\begin{array}{l}\text { Merumuskan masalah } \\
\text { merupakan langkah membawa } \\
\text { siswa pada suatu persoalanyang } \\
\text { mengandung teka-teki. } \\
\text { Persoalan yang disajikan adalah } \\
\text { persoalan yang menantang } \\
\text { siswa untuk berpikir } \\
\text { memecahkan teka-teki itu. }\end{array}$ \\
\hline $\begin{array}{l}\text { Merumuskan } \\
\text { Hipotesis }\end{array}$ & $\begin{array}{l}\text { Hipotesis adalah jawaban } \\
\text { sementara dari suatu } \\
\text { permasalahan yang sedang } \\
\text { dikaji. Sebagai jawaban } \\
\text { sementara, hipotesis perlu diuji } \\
\text { kebenarannya. }\end{array}$ \\
\hline $\begin{array}{l}\text { Mengumpulk- } \\
\text { an data }\end{array}$ & $\begin{array}{l}\text { Mengumpulkan data adalah } \\
\text { aktivitas menjaring informasi } \\
\text { yang dibutuhkan untuk menguji } \\
\text { hipotesis yang diajukan. }\end{array}$ \\
\hline $\begin{array}{l}\text { Menguji } \\
\text { Hipotesis }\end{array}$ & $\begin{array}{lrr}\text { Menguji hipotesis adalah } \\
\text { menentukan jawaban yang } \\
\text { dianggap diterima sesuai } \\
\text { dengan } & & \\
\text { data atau informasi yang } \\
\text { diperoleh } \\
\text { pengumpulan data. }\end{array}$ \\
\hline $\begin{array}{l}\text { Merumuskan } \\
\text { Kesimpulan }\end{array}$ & $\begin{array}{l}\text { Merumuskan kesimpulan adalah } \\
\text { proses mendeskripsikan temuan } \\
\text { yang diperoleh berdasarkan } \\
\text { hasil pengujian hipotesis. Untuk } \\
\text { mencapai kesimpulan yang } \\
\text { akurat } \\
\text { sebaiknya guru mampu } \\
\text { menunjukkan pada siswa data } \\
\text { mana yang relevan. }\end{array}$ \\
\hline
\end{tabular}

\section{Metode}

Dalam penelitian ini, metode yang digunakan oleh peneliti adalah model kuasi eksperimen (Ruseffendi, 2005). Populasi dalam penelitian ini, yaitu kelas $X$ pada salah satu SMA di Kabupaten Garut tahun pelajaran 2019/2020. Sampel penelitian yaitu kelas $X$ IPS 1 yang mendapatkan model pembelajaran Pembelajaran berbasis Masalah (eksperimen 1) sebanyak 36 siswa, dan kelas X IPS 4 yang mendapatkan model pembelajaran Inkuiri (eksperimen 2) dengan sebanyak 30 siswa. Jadi, jumlah siwa yang ikut serta dalam penelitian ini sebanyak 66 orang siswa.

Adapun desain penelitian yang digunakan adalah desain penelitian yang dikemukakan oleh (Ruseffendi, 2005) sebagai berikut.

$\begin{array}{ccc}0 & x_{1} & 0 \\ 0 & x_{2} & 0\end{array}$

Keterangan:

$\mathrm{O}=$ Tes awal (pretest) dan tes akhir (posttest)

$\mathrm{X}_{1}=$ Perlakuan pada kelas eksperimen 1 dengan Model pembelajaran Problem Based Learning

$\mathrm{X}_{2}=$ Perlakuan pada kelas eksperimen 2 dengan Model pembelajaran Inkuiri $---\quad=$ Kuasi eksperimen

Analisis data dilakukan untuk mengetahui hasil dari penelitian setelah diberikan perlakuan model pembelajaran. Data yang dianalisis diperoleh dari hasil Pretest, Posttest, Gain Ternormalisasi dan penyebaran angket.

\section{Hasil dan Pembahasan}

Hasil penelitian ini meliputi pretest, tes akhir posttest kemampuan representasi matematis dan hasil penyebaran angket. Dari data hasil penelitian dengan dua kelas yang berbeda yaitu kelas X IPS 1 sebagai kelompok yang mendapatkan model pembelajaran Pembelajaran berbasis Masalah disebut kelas eksperimen 1 dan 
kelas X IPS 4 sebagai kelompok yang mendapatkan model pembelajaran Inkuiri disebut kelas eksperimen 2. Kedua kelas tersebut diberikan pretest dan posttes dengan hasil sebagai berikut.

Tabel 3.

Data Hasil Penelitian

\begin{tabular}{|c|c|c|c|c|c|c|}
\hline \multicolumn{3}{|c|}{ Kelompok } & $\begin{array}{l}X_{m a} \\
k s\end{array}$ & $x_{\min }$ & $\bar{x}$ & $s$ \\
\hline \multirow{6}{*}{$\begin{array}{l}\text { Pembelajar } \\
\text { an berbasis } \\
\text { Masalah }\end{array}$} & Pretes & \multirow{6}{*}{6} & 13 & 0 & 4,31 & 3,0 \\
\hline & $t$ & & & & & 3 \\
\hline & Postte & & 20 & 9 & 14,5 & 3,1 \\
\hline & st & & & & 8 & 7 \\
\hline & Gain & & 1,0 & 0,3 & 0,67 & 0,1 \\
\hline & & & 0 & 6 & & 9 \\
\hline \multirow[t]{6}{*}{ Inkuiri } & Pretes & & 8 & 1 & 4,50 & 1,6 \\
\hline & $t$ & \multirow[t]{5}{*}{0} & & & & 6 \\
\hline & Postte & & 18 & 6 & 11,6 & 3,5 \\
\hline & st & & & & 7 & 8 \\
\hline & Gain & & 0,8 & 0,1 & 0,46 & 0,2 \\
\hline & & & 7 & 3 & & 3 \\
\hline
\end{tabular}

Dapat dilihat dari tabel 3 kemampuan awal dari kelompok sebelum diberikan perlakuan model pembelajaran terdapat kesamaan pretest antara kelas Pembelajaran berbasis Masalah dan Inkuiri dengan selisih nilai rata-rata pretest dari kedua kelompok sebesar 0,19.

Begitu pula dengan kemampuan representasi siswa yang diuji dari hasil nilai posttest. Dapat dilihat dari tabel nilai posstest kelas Pembelajaran berbasis Masalah dan kelas Inkuiri memiliki selisih yang cukup besar yaitu 2,91 secara deskripsi terdapat perbedaan.

Untuk peningkatan kemampuan representasi matematis untuk kelas Pembelajaran berbasis Masalah dan kelas Inkuiri berturut-turut memiliki rata-rata 0,67 dan 0,46 berinterpretasi sedang. Nilai rata-rata posttest yang didapat pada kelompok siswa dengan model pembelajaran Pembelajaran berbasis Masalah memiliki pencapaian sekitar 73,00\% jika dibandingkan dengan skor ideal yang harus dicapai oleh siswa. Namun, kelompok dengan model pembelajaran Inkuiri hanya sekitar 58\% dari skor ideal yang diharapkan.

Adapun ketercapaian aspek kemampuan representasi dapat dilihat dari Tabel 4 sebagai berikut.

Tabel 4.

Ketercapaian Aspek Kemampuan Representasi

\begin{tabular}{llllllll|}
\hline \multicolumn{1}{l}{ Model } & \multicolumn{6}{c}{ Aspek (\%) } & Rata- \\
\cline { 2 - 6 } Pembelajaran & $1 \mathrm{a}$ & $1 \mathrm{~b}$ & 2 & 3 & 4 & rata \\
\hline $\begin{array}{l}\text { Pembelajaran } \\
\text { berbasis } \\
\text { Masalah }\end{array}$ & 81 & 28 & 98 & 91 & 67 & 73 \\
\hline Inkuiri & 82 & 58 & 88 & 48 & 16 & 58 \\
\end{tabular}

Dapat dilihat pada Tabel 4 kelas Pembelajaran berbasis Masalah dan kelas Inkuiri memiliki selisih rata-rata kemampuan representasi untuk kelas Pembelajaran berbasis Masalah dan kelas Inkuiri adalah 15\%.

Untuk ketercapaian setiap aspek kemampuan representasi kelas Pembelajaran berbasis Masalah hanya satu aspek yang tidak mencapai ketuntasan yaitu aspek representasi kata atau teks dengan indikator menjawab soal dengan kata-kata atau teks tulis pada tulis nomor soal 1b. Sedangkan untuk kelas Inkuiri terdapat 3 aspek yang tidak mencapai ketuntasan yaitu aspek kata atau teks tulis (indikator menjawab soal dengan kata-kata atau teks), representasi gambar, dan representasi persamaan atau ekspresi matematika.

Instrumen yang digunakan untuk mengetahui sikap siswa yaitu menggunakan angket. Angket diberikan 
kepada siswa yang telah mendapatkan perlakuan dengan model pembelajaran Pembelajaran berbasis Masalah dan Inkuiri di akhir pertemuan penelitian untuk meneliti sikap siswa terhadap pembelajaran matematika, terhadap model pembelajaran Pembelajaran berbasis Masalah dan Inkuiri, dan terhadap kemampuan representasi matematis. Pengolahan data yang digunakan untuk menganalisis sikap-sikap tersebut menggunakan skala lima dengan mengacu pada skala Likert yang menunjukan persentase terbesar skala sikap siswa secara umum pada kelompok eksperimen 1 adalah 63,61\% termasuk kategori cukup, dan pada kelompok eksperimen 2 adalah $65,51 \%$ juga termasuk kategori cukup. Sebelum diberikan perlakuan model pembelajaran, kedua kelas diberikan pretest terlebih dahulu untuk mengetahui kemampuan awal yang dimiliki siswa. ratarata pretest pada masing-masing kelas yaitu 4,31 dan 4,50. Data tersebut kemudian di uji normalitasnya menggunakan uji Lilliefors dengan taraf signifikansi 5\% diperoleh bahwa kelas Pembelajaran berbasis Masalah tidak berdistribusi normal sedangkan kelas Inkuiri berdistribusi normal sehingga uji Mann Whitney dilakukan pada langkah selanjutnya. Dengan menggunakan uji dua pihak diperoleh nilai Zhitung $=-1,375$ dan $z_{\text {tabel }}=1,96$ berada pada daerah penerimaaan $\mathrm{H}_{\mathrm{o}}$ yaitu $-\mathrm{z}_{\text {tabel }} \leq \mathrm{z}_{\text {hitung }} \leq \mathrm{z}_{\text {tabel }}$. Hal ini menunjukan kemampuan awal pada kedua kelas sama atau tidak berbeda.
Berdasarkan hasil posttest diperoleh rata-rata untuk kelas Pembelajaran berbasis Masalah dan kelas Inkuiri berturut-turut adalah 14,58 dan 11,67. Data hasil posttest juga diuji normalitasnya menggunakan uji Lilliefors dengan taraf signifikansi 5\% diperoleh bahwa kelas Pembelajaran berbasis Masalah tidak berdistribusi normal sedangkan kelas Inkuiri berdistribusi normal sehingga uji Mann Whitney dilakukan pada langkah selanjutnya. Dengan menggunakna uji satu pihak dan taraf signifikan 0,05 diperoleh nilai $z_{\text {hitung }}=3,074$ dan $z_{\text {tabel }}=1,64$ berada pada daerah penerimaan $\mathrm{H}_{\mathrm{a}}$ : $\mathrm{z}_{\text {hitung }}>\mathrm{z}_{\text {tabel }}$

Sehingga dapat disimpulkan bahwa: Kemampuan representasi matematis siswa yang mendapatkan model pembelajaran Pembelajaran berbasis Masalah lebih baik dibandingkan dengan siswa yang mendapatkan model pembelajaran Inkuiri.

Adapun rincian peningkatan kemampuan representasi matematis kelas Pembelajaran berbasis Masalah dan kelas Inkuiri disajikan pada Tabel 5 berikut.

Tabel 5.

Data Persentase Interpretasi Peningkatan Kemampuan Representasi Matematis

\begin{tabular}{lllll}
\hline Interpretasi & \multicolumn{2}{l}{ PBM } & \multicolumn{2}{l}{ Inkuiri } \\
\cline { 2 - 5 } $\begin{array}{l}\text { Gain } \\
\text { Ternormalisasi }\end{array}$ & $\mathrm{f}_{\mathrm{i}}$ & $\mathbf{( \% )}$ & $\mathrm{f}_{\mathrm{i}}$ & $\mathbf{( \% )}$ \\
\hline Rendah & 0 & 0 & 11 & 37 \\
\hline Sedang & 24 & 67 & 13 & 43 \\
\hline Tinggi & 12 & 33 & 6 & 20 \\
\hline Jumlah & 36 & 100 & 30 & 100 \\
\hline
\end{tabular}

Data dari angket siswa yang telah terkumpul, kemudian data diubah ke dalam bentuk interval dengan menggunakan Method of Succesive Interval (MSI). Adapun 
sikap siswa terhadap pembelajaran matematika secara umum sebagai berikut.

Tabel 6.

Analisis Angket Secara Umum

\begin{tabular}{lllll|}
\hline Kelas & $\boldsymbol{n}$ & $\begin{array}{l}\text { Skor } \\
\text { Total }\end{array}$ & $\begin{array}{l}\text { Skor } \\
\text { Ideal }\end{array}$ & Interpretasi \\
\hline PBM & 36 & 4032,5 & 6339 & Cukup \\
\hline Inkuiri & 30 & 3303,6 & 5043 & \\
\hline
\end{tabular}

Setelah melakukan pretest selama proses kegiatan pembelajaran berlangsung, peneliti melakukan observasi untuk mengetahui perkembangan proses pembelajaran setiap pertemuan. Pada kelas kelas Pembelajaran berbasis Masalah aktifitas guru dari empat pertemuan yang dilakukan dengan 25 aspek yang amati 90\% kegiatan pembelajaran sudah sesuai dengan sintaks model pembelajaran dan aktifitas siswa 79\% kegiatan pembelajaran yang dilakukan sudah terlaksana sesuai dengan sintaks model pembelajaran. Sedangkan pada kelas Inkuiri dari empat pertemuan yang dilakukan dengan 24 aspek yang amati $86 \%$ kegiatan pembelajaran yang dilakukan guru sudah sesuai dengan sintaks model pembelajaran, dan aktifitas siswa $70 \%$ kegiatan pembelajaran yang dilakukan siswa sudah terlaksana sesuai dengan sintaks model pembelajaran.

Faktor-faktor yang mempengaruhi hasil penelitian antara lain:

1. Gaya Belajar

Gaya belajar (Sundayana, 2016) merupakan kebiasaan siswa dalam memproses bagaimana menyerap informasi, pengalaman, serta kebiasaan siswa dalam memperlakukan pengalaman yang dimilikinya Pada dasarnya setiap siswa mempunyai gaya belajar yang berbedabeda. Dari hal tersebut, akan berdampak pada keragaman siswa dalam cara belajarnya.

Kelompok eksperimen 1 cenderung dapat diarahkan dan dapat dengan mudah menerima pembelajaran, hal ini dapat peneliti lihat ketika proses pembelajaran berlangsung. Dan juga terlihat antusias ketika guru mengajukan permasalahan mereka terdorong untuk memecahkan masalah melalui diskusi secara kelompok. Hal ini sesuai dengan pendapat Tan (dalam Nasution, 2018) bahwa Pembelajaran berbasis Masalah merupakan inovasi dalam pembelajaran karena dalam Pembelajaran berbasis Masalah kemampuan berfikir siswa betul-betul dioptimalisasikan melalui proses kerja kelompok atau tim yang sistematis, sehingga siswa dapat memberdayakan, mengasah, menguji dan mengembangkan kemampuan berpikirnya secara berkesinambungan.

Beda halnya dengan kelompok eksperimen 2 cenderung tidak aktif dan kurang mendengarkan apa yang di sampaikan oleh guru, hanya beberapa siswa yang memiliki minat serta motivasi belajar sehingga dalam adaptasi model pembelajaran pun guru memerlukan waktu sampai dua kali pertemuan. Pembelajaran berbasis Inkuiri merupakan pembelajaran yang didasarkan dari teori-teori belajar konstruktivisme. Salah satu prinsip teori belajar konstruktivisme adalah bahwa siswa tidak boleh hanya sekedar menerima begitu saja informasi, pengetahuan atau pun materi namun siswa juga harus mampu menemukan dan membangun pengetahuan mereka sendiri.

Penelitian yang dilakukan oleh (Eviyanti, 2018) bahwa peningkatan kemampuan representasi matematis siswa dipengaruhi 
oleh model pembelajaran berbasis masalah. Dalam penelitian lain (Fitri, Munzir, \& Duskri, 2017) bahwa peningkatan kemampuan representasi matematis dipengaruhi oleh model pembelajaran. Dalam hal ini model pembelajaran yang mempengaruhinya adalah model Pembelajaran berbasis Masalah.

Meskipun hasil peningkatan kemampuan representasi dari kedua kelompok belum optimal setelah diberikan pembelajaran menunjukkan interpretasi sedang. Hal ini dikarenakan model pembelajaran yang baru dan asing bagi siswa serta keterbiasaan siswa mengerjakan soal soal yang diberikan maupun soal dalam LKS atau latihan mandiri. Selain itu, kedua kelompok mendapat jadwal siang hari bahkan sore hari sehingga mengakibatkan siswa kemampuan siswa maupun respon siswa terhadap kegiatan pembelajaran menurun dan menyebabkan rendahnya daya serap siswa terhadap materi yang diberikan.

2. Minat dan Motivasi Belajar

Pada model pembelajaran Pembelajaran berbasis Masalah guru membantu investigasi mandiri dan kelompok, sehingga siswa harus memiliki minat serta motivasi sendiri untuk belajar. Teori Piaget (Nasution, 2018) memandang perkembangan kognitif sebagai suatu proses dimana anak secara aktif membangun sistem makna dan pemahaman realitas melalui pengalamanpengalaman dan interaksi-interaksi mereka.

Model pembelajaran Inkuiri diawali dengan siswa orientasi dan diakhiri dengan merumuskan kesimpulan dari berbagai hipotesis yang diajukan. Gulo (Annisa, 2017) berpendapat bahwa Inkuiri tidak hanya mengembangkan kemampuan intelektual, tetapi seluruh potensi yang ada termasuk pengembangan emosional dan keterampilan yang prosesnya bermula dari merumuskan masalah, merumuskan hipotesis, mengumpulkan data, menganalisis data, dan membuat kesimpulan.

Setiap melakukan pembelajaran siswa harus memiliki minat dan motivasi sehingga akan tercapai tujuan pembelajaran. Pada penelitian yang dilakukan oleh (Farhan \& Retnawati, 2014; Khasanah, Supandi, \& Kartinah, 2021) menyatakan bahwa model pembelajaran Pembelajaran berbasis Masalah dan model pembelajaran Inkuiri efektif untuk meningkatkan kemampuan representasi matematis. Namun, apabila siswa tidak memiliki minat dan motivasi untuk belajar maka pembelajaran akan tidak bermakna, untuk kelompok eksperimen 1 siswa sudah menunjukan minat serta motivasi untuk belajar, beda halnya dengan kelompok eksperimen 2 sebagian besar tidak memiliki minat serta motivasi untuk belajar matematika.

3. Analisis Jawaban Siswa

Dilihat dari penyelesaian siswa pada kedua kelas model pembelajaran yang diberikan, siswa masih belum memahami benar bagaimana cara memodelkan atau mengekspresikan permasalahan nyata ke dalam bentuk matematika. Soal ini melibatkan permasalahan konstektual diharapkan siswa dapat mengekspresikan permasalahan tersebut ke dalam bentuk 
matematika dilanjutkan dengan

menyelesaian permasalahan tersebut.

Pada kelompok eksperimen 1 sebagian siswa dapat mengekspresikan masalah konstekstual ke dalam bentuk matematika sehingga tidak terjadi kesulitan dalam menyelesaikan permasalahan. Siswa yang memiliki skor tidak sempurnapun dapat mengekspresikan permasalahan, namun kesalahan terletak pada pengerjaan yang tidak tuntas, dan ada beberapa bagian yang tidak sesuai dengan kaidah penskoran. Sehingga hal tersebut mempengaruhi pada nilai yang di dapat oleh siswa. Dari 36 siswa kelas Pembelajaran berbasis Masalah 10 orang mendapatkan skor sempurna yaitu 4 sebanyak dua belas siswa mendapatkan skor 3 sebanyak sepuluh siswa mendapatkan skor 2 sebanyak satu orang mendapatkan skor 1 dan sebanyak 3 orang tidak menjawab soal yang berarti memiliki skor 0.

Pada kelompok eksperimen 2 menjawab soal dengan tidak tuntas dan kurang sesuai dengan kaidah penskoran, siswa tidak menyatukan gambar dan mengarsir irisan dari kedua gambar tersebut sehingga tidak dapat ditarik kesimpulan dari penyelesaian. Pada kelas Inkuiri hanya sebagian siswa yang sudah dapat mengekspresikan masalah konstekstual ke dalam bentuk matematika. kebanyakan dari mereka tidak dapat menjawab soal nomor 4 yang berarti mereka tidak bisa mengekspresikan masalah kedalam bentuk matematika. Dari 30 siswa tidak ada yang mendapat skor sempurna, hanya ada 4 orang yang menjawab soal dengan skor 3, 7 orang dengan skor 1, dan 19 orang tidak menjawab soal yang berarti memiliki skor 0.
4. Sikap Siswa Terhadap Model Pembelajaran

Interpretasi sikap siswa terhadap mata pelajaran matematika dengan model pembelajaran Pembelajaran berbasis Masalah dan model pembelajaran Inkuiri mendapat tanggapan cukup. Peneliti beranggapan bahwa hal tersebut terjadi karena beberapa siswa tidak mengikuti kegiatan pembelajaran dengan sungguhsungguh. Model pembelajaran Pembelajaran berbasis Masalah dan model pembelajaran Inkuiri merupakan model pembelajaran yang baru diterapkan pada kelas yang digunakan oleh peneliti sehingga siswa harus menerapkan kebiasaan belajar baru. Mereka dituntut untuk belajar secara aktif baik individu maupun kelompok, dengan cara belajar seperti ini ada beberapa siswa yang tidak menyukainya. Ia lebih memilih belajar matematika dengan cara guru yang menjadi pusat pembelajaran. Namun demikian, sebagian ada beberapa siswa dari kedua kelas penelitian dapat mengikuti pembelajaran dengan baik saat menggunakan model pembelajaran.

\section{Penutup}

Kesimpulan dari penelitian ini sebagai berikut: 1) Kemampuan representasi matematis siswa yang mendapatkan model pembelajaran Pembelajaran berbasis Masalah lebih baik dibandingkan dengan siswa yang mendapatkan model pembelajaran Inkuiri. 2) Kualitas peningkatan kemampuan representasi matematis siswa kelas Pembelajaran berbasis Masalah berdasarkan hasil analisis gain ternormalisasi dengan rata-rata 0,67 sehingga interpretasinya sedang. 
Kualitas peningkatan kemampuan representasi matematis siswa kelas Inkuiri berdasarkan hasil analisis gain ternormalisasi dengan rata-rata 0,46 sehingga interpretasinya sedang. 4) Sikap siswa terhadap pembelajaran matematika dengan menggunakan model pembelajaran Pembelajaran berbasis Masalah berinterpretasi cukup. 5) Sikap siswa terhadap pembelajaran matematika dengan menggunakan model pembelajaran Inkuiri berinterpretasi cukup.

\section{DAFTAR PUSTAKa}

Abdi, J., Ikhsan, M., \& Marwan. (2013). Meningkatkan kemampuan Siswa Sekolah Menengah Atas dalam menyelesaikan soal matematika setara PISA Melalui pendekatan kontruktivisme. Jurnal Peluang, 1(2), 51-62.

Amalia, A. R., Rusdi, R., \& Kamid, K. (2021). Pengembangan Soal Matematika Bermuatan HOTS Setara PISA Berkonteks Pancasila. Jurnal Cendekia: Jurnal Pendidikan Matematika,5(1), 01-19.

Annajmi, A., \& Afri, L. E. (2019). Pengaruh Penggunaan Lembar Aktivitas Siswa Berbasis Metode Penemuan Terbimbing terhadap Peningkatan Kemampuan Representasi Matematis Siswa. Mosharafa: Jurnal Pendidikan Matematika, 8(1), 95-106.

Annisa, S. (2017). Efektivitas Model Inquiry Learning Ditinjau dari Kemampuan Representasi Matematis dan Self Confidence Siswa. Skripsi Fakultas Keguruan Dan Ilmu Pendidikan Universitas Lampung: Tidak Diterbitkan.

Damayanti, R., \& Afriansyah, E. A. (2018). Perbandingan Kemampuan Representasi Matematis Siswa antara
Contextual Teaching and Learning dan Problem Based Learning. JIPM (Jurnal Ilmiah Pendidikan Matematika), 7(1), 30-39.

Eviyanti, C. Y. (2018). Perbedaan Peningkatan Kemampuan Representasi Matematis Dan Self Confidence Siswa Pada Pembelajaran Berbasis Masalah dan Pembelajaran Biasa. Judika Education (Jurnal Pendidikan Matematika), 1(2), 93-104.

Farhan, M., \& Retnawati, H. (2014). Keefektivan PBL Dan IBL Ditinjau dari Prestasi Belajar, Kemampuan Representasi, dan Motivasi Belajar. Jurnal Riset Pendidikan Matematika, 1(2), 227-240.

Fitri, N., Munzir, S., \& Duskri, M. (2017). Meningkatkan

Kemampuan Representasi Matematis melalui Penerapan Model Problem Based Learning. Jurnal Didaktik Matematika. 4(1), 59-67.

Guntara, Y., \& Nona, M. M. (2019). Integrasi Inquiry Training: Pengembangan Physics Subject Specific Pedagogy Untuk Meningkatkan Kemampuan Representasi Matematis Siswa SMA. Gravity: Jurnal IImiah Penelitian dan Pembelajaran Fisika, 5(2).

Handayani, M. (2014). Mengatasi kesulitan representasi matematis Siswa pada materi SPLDV menggunakan wawancara klinis Kelas X SMA. Jurnal Pendidikan Dan Pembelajaran, 3(8), 110.

Khasanah, I., Supandi, S., \& Kartinah, K. (2021). Efektivitas Model Pembelajaran Think Talk Write (TTW) Melalui Pendekatan Saintifik dan Open-Ended Terhadap Kemampuan Representasi Matematis Siswa. Imajiner: Jurnal Matematika dan Pendidikan Matematika,3(2), 115-121. 
Kusuma, A. M., \& Candramila, W. (2017). Respon Siswa terhadap Pembelajaran Berbasis Masalah pada Materi Pencemaran Lingkungan di Kelas $X$ SMA.Jurnal Pendidikan dan Pembelajaran Khatulistiwa, 6(10).

Lambertus, L., Ambarsari, M., \& Maonde, F. (2016). Pengaruh Sikap Siswa terhadap Hasil Belajar Matematika melalui Kombinasi Model Pembelajaran Kooperatif. Jurnal Pendidikan Matematika, 7(2), 105124.

Lestari, S., Andinasari, A., \& Retta, A. M. (2020). Model Pembelajaran Generatif Untuk Meningkatkan Kemampuan Representasi Matematis Peserta Didik. IndoMath: Indonesia Mathematics Education, 3(1), 44-51.

Maryati, I. (2016). Upaya Meningkatkan Kemampuan Pemecahan Masalah Matematik Siswa Sekolah Menengah Pertama melalui Pembelajaran Kontekstual. 7(1), 1-9.

Nasution, D. (2018). Pengaruh Pembelajaran Problem Based Learning (PBL) Terhadap Kemampuan Representasi Matematis Siswa di Kelas VIII Yayasan Perguruan Islam SMP Cerdasmurni Tembung. Fakultas IImu Tarbiyah Dan Keguruan Universitas Islam Negeri Sumatera Utara: Tidak Diterbitkan [Online].

Noer, S. H. \& Gunowibowo, P. (2018). Efektivitas Problem Based Learning Ditinjau dari Kemampuan Berpikir Kritis dan Representasi Matematis. JPPM (Jurnal Penelitian Dan Pembelajaran Matematika), 11(2), 1732.

Putri, H. E. (2017). Penerapan Model Pembelajaran Kooperatif dengan Strategi Konflik Kognitif untuk Meningkatkan Kemampuan Representasi Matematis Siswa SMA. Syntax Literate; Jurnal IImiah Indonesia, 2(12), 50-61.
Ruseffendi, E. T. (2005). Dasar-Dasar Penelitian Pendidikan dan Bidang NonEksakta Lainnya. Bandung: Tarsito.

Sanjaya, W. (2008). Strategi Pembelajaran Berorientasi Standar Proses Pendidikan. Jakarta: Kencana Prenada Media Group.

Sundayana, R. (2016). Kaitan antara Gaya Belajar, Kemandirian Belajar, dan Kemampuan Pemecahan Masalah Siswa SMP dalam Pembelajaran Matematika. Mosharafa: Jurnal Pendidikan Matematika, 5(2), 75-84.

Yenni, Y., \& Sukmawati, R. (2020). Analisis Kemampuan Representasi Matematis Mahasiswa Berdasarkan Motivasi Belajar. Mosharafa: Jurnal Pendidikan Matematika, 9(2), 251-262.

Zaini, L. M. H. (2017). Efektivitas Model Pembelajaran Inkuiri Terhadap Kemampuan Representasi Matematika Siswa Kelas XI MA Al-Ikhlasiyah Perempuan Tahun Pelajaran 2016/2017. Universitas Islam Negeri (UIN) Mataram: Tidak Diterbitkan [Online].

\section{Riwayat Hidup PenUlis}

\section{Dr. Iyam Maryati, M.Pd.}

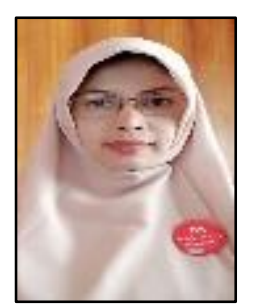

Lahir di Garut, 29 Oktober 1981. Dosen Tetap Yayasan Institut Pendidikan Indonesia Garut. S1-STKIP Garut, lulus tahun 2006; S2--Universitas Pasundan, Bandung, lulus tahun 2012. Dan S3-Universitas Pendidikan Indonesia lulus tahun 2019 pada Program Studi Pendidikan Matematika.

\section{Vera Monica, S.Pd.}

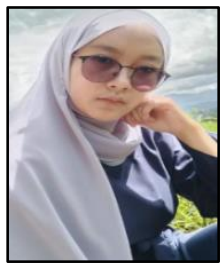

Lahir di Garut, 13 Februari 1998. S-1 Program Pendidikan Matematika, Institut Pendidikan Indonesia Garut lulus tahun 2020. 